\title{
THE EXTENT TO WHICH THE PRACTICE OF NOT BURNING CANE TRASH HAS BEEN ADOPTED IN PUERTO RICO
}

By George N. Wolco'T, Entomologist, Insular Experiment Station, Río Piedras, P. R.

For many years, most entomologists working on the problem of the control of the sugar-cane moth stalk borer, Diatraea saccharalis $F$., have been of the opinion that the burning of cane trash in the field, either before or after harvesting, farored the borer because the fire destroyed its natural enemy, the egg-parasite, Trichogramma. minutum Riley, and have therefore unceasingly recommended to cane growers that the trash should not be burned when the fields are to be ratooned. Only in Puerto Rico have these recommendations been at all widely adopted, but no definite data heretofore have been available to show the extent to which the planters were following the practise of cutting cane without burning the trash, and raking it into alternate rows to permit of cultivation and irrigation of the ratoon cane.

On April 3d, 4th and 5th, 1933, the writer, accompanied by Mr. Richard Faxon, in charge of the local unit of the federal Bureau of Plant Quarantine, and Mr. U. C. Loftin, Senior Entomologist of Cotton Insect Investigations, U. S. Bureau of Entomology, made a trip around the island, and noted every field readily observable from the road in which the trash had, or had not, been burned. Before giving the figures, it should be noted that non-burning the trash is essentially a negative practise, and that the trash had not been burned at the time of observation does not by any means indieate or prove that it might not be burned later. To more than compensate for this error, due to not being able to predict what might happen in the future, is the fact that if the trash is burned before eutting, this is readily observable even before the cane is cut, and is giren credit under the heading of "burned". Furthermore, it is impossible to determine until a field is actually being plowed, whether it is to be left for ratoons or plowed for planting, and it is quite possible that some fields recorded as "burned" will eventually be plowed, and should not have been entered. No entomologist has considered recommending non-burning of trash in fields to be plowed for planting, yet one field was observed at Central Mercedita, Ponee, which was being fitted for planting, and in which, very obviously, the trash had not been burned. It should also be noted that the practise of burning cane 
before cutting is most exceptional in Puerto Rico, yet it had been rather widely adopted this year in the northeastern corner of the island, where the damage to standing cane caused by the hurricane of San Ciprián, September 26-27, 1932, was greatest. In ordinary years, such a practise would practically never be followed in this part of the island.

In further explanation of the method used in making the observations, it should be stated that a field is considered to be any area, however large or small, receiving the same treatment at the same time. The enormous differences in size of field by this definition, might introduce a considerable error if only a few fields had been observed; but as the observations numbered five hundred four, it is considered that the figures as given present an essentially true picture. If the trash is burned in part of a field, and not burned in the other part, for the purpose of this investigation it is considered to be two fields.

Method of Disposal of Cane Trash in Fields to be Katooned in Puerto Rico, observed at the height of the grinding season (April 3, 4 and 5) 1933.

\begin{tabular}{|c|c|}
\hline Trash not burned & Trash burned \\
\hline San Juan to Maunabo (Northeast coast)-_-_- 115 & 32 \\
\hline Maunabo to Ponce (Southeast coast) -_-_-_ 81 & 7 \\
\hline Ponce to Mayagüez (Sruthwest coast)_____-_ 85 & 14 \\
\hline Mayagüez to San Juan (Northwest coast) & 24 \\
\hline 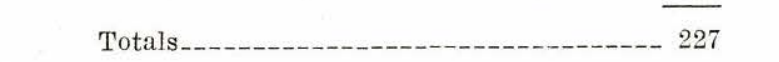 & 77 \\
\hline
\end{tabular}

Per cent.

84.7

15. 3 